\title{
The Legal Basis of Public Participation in the International Environmental Governance as a Requirement for Sustainable Development
}

\author{
By O. V. Pavlova ${ }^{1}$
}

\begin{abstract}
The paper focuses on the global environmental governance and features of public participation as an integral element of sustainable development. Recently, sustainable development and environmental governance have become interrelated elements of social development. The requirements to strengthen the role of civil society, especially representatives of the public, under the new or reformed system of international environmental governance are important issue of the article. The civil society should play a major role in five key areas: collection and dissemination; policy development consultation; implementation of environmental policy; monitoring and evaluation; promotion of environmental justice. The author defines the features of powers' separation between the actors in international environmental governance, enlightens the question of the public environmental management and its role in environmental decision-making. Thus, determination of the usefulness of the international environmental governance model for the national systems of law is up to date. The research of the peculiarities of the realization of public participation in the international environmental governance is consider to be of the highest relevance, and the development of public environmental management as a distinct element of environmental governance is the issue for the further investigations.
\end{abstract}

Keywords: public, public environmental governance, international environmental governance, sustainable development, public participation.

\section{Introduction}

The environment is major public acquisition the use and management of what straight influence on public. Conception of public participation as legal procedure in development of politics and international ecological management develops and acquires a legal form. Steady development and ecological management become the connected elements of society development as a noncontiguous and relating item of triad: ecological, economic and public directions.

In the most develop democratic countries the participation of public has a legal expression. An international ecological management also needs the realization of right for public on participating in accepted ecologically meaningful decisions with the aim of strengthening of the democratic system of ecological management, providing of accountability, transparency and not declarative, but actual realization of public ecological management. 


\section{Purpose}

The aim of research is the legal understanding of participation of public in an international ecological management as an inalienable element of conception of steady development on the base of international experience and search of methods of his perfection at national level, including by application of positive experience.

\section{Methods}

There were the used methods of legal analysis, deductive and inductive determination and correlation of concepts that is used in an international ecological management, and also synthesis, - for the sake of determination of possibility of application of positive international experience in the national system of public ecological management and participation of public in an ecological management on the whole.

\section{Results}

The concept of international management leans against considerable history of researches of international ecological cooperation, beginning from the Stockholm conference of 1972 on the problems of natural environment of humanity that had results in the first wave of scientific researches in area of intergovernmental collaboration in industry of guard of natural environment and organization of their activity $[1 ; 2 ; 3]$.

For today the most actual predecessor of conception of global management is a discussion of international ecological processes of 1980th [4; 5] and in 1990th, including negotiations in relation to creation of the modes of ecological defense of natural environment, and also possible efficiency of their maintenance $[6 ; 7 ; 8]$.

Now a discussion lasts in relation to strengthening of role of civil society, and especially nongovernmental organizations, within the framework of the new or reorganized system of international ecological management. A question appears in that civil society must costar in five key spheres: collection and distribution of information; development of politics of consultation; realization of ecological politics; estimation and monitoring; propaganda of ecological justice.

As, in opinion of B. Gemmill and A. Bamidele-Izu, existent structures do not allow to civil society to execute these functions effectively and to make suggestions in relation to reformation of measures on an assistance to participation of public in an international ecological management [9, p.4].

Although the states are primary subjects in an international ecological management, universally recognized, that the systematic bringing in of civil society promotes efficiency of ecological management, providing facilities for the incorporated interests and prospects that cannot differently be presented to the governments, than as through direct participation of public in the process of making decision.

The importance of civil society participation has been recognize in international environmental law and policy, notably in principle 10 of the Declaration of Rio +20 Environment and Development. 
United Nations formed a "draft guidelines for the participation of major groups and stakeholders in policy development" [10], which updates the understanding that "major groups and stakeholders can be made a significant contribution to improving our understanding of the natural environment, develop innovative solutions to the environmental problems."

To determine the elements of international environmental governance, public environmental management is an integral part of it. According to J. Verksman and J. Foti, the UN Conference on Sustainable Development Rio +20 in its provisions establishes the need for the international community to move and carry out significant reforms in international environmental governance - modification institutions and procedures through which governments implement international environmental law and policies. Decisions of international environmental governance affect all three pillars of sustainable development: economic, social and environmental [11].These decisions must strengthen the public support for reform of international environmental governance, which should lead to the creation of new opportunities for civil society to fulfill four main roles in environmental decisions, observe, inform and shape policy and to cooperate.

Noteworthy issues related to the definition of civil society consisting of representatives of business and industry, which must include this social group. While in Agenda 21 [12] business and industry are consider part of civil society, some observers argue that since they already have a significant impact on international processes management through informal lobbying capabilities and impact of formal channels - business and industry should not be included in the civil society.

Although changes in the conditions of international governance needs, they are not a panacea for achieving sustainable development goals. The lack of coherence in official international institutional structures reflects the high level of inconsistency as to how pronounced is effective and appropriate approach to achieve sustainable development. The inability of the international community agreed to a common approach to sustainable development international environmental governance is largely rooted in the gap between the perspectives and priorities of developed countries. Reducing and overcoming these differences are important prerequisites for an effective, efficient and fair system of sustainable environmental management [13].

However, I disagree with the majority opinion of scientists that members of the international environmental management on the part of the public can be extremely NGOs. I believe that the parties may also citizens who can be recognize as an experts on environmental management issues or environmental sustainability. Thus, we propose to introduce a new category of members. Thus, we can achieve a high level of peer review of the situation. These citizens will have to pass accreditation and have a specialized degree or law degree and proof of qualification. Assignment shall take place on a competitive basis, and therefore be extremely specialized.

We believe that no international organization can fulfill unifying role for public participation in international environmental governance, now they realize the model of public participation in consultative status, but its scope does not give the right to participate actively, and their comments recommendation character only.

However, the universalism environmental law should promote the establishment of 
common principles, in the spirit of the Aarhus Convention on Access to Information, Public Participation in Decision-making and Access to Justice in Environmental Matters. Compares with the national legal doctrine environmental management study in Ukraine, the researchers measured nominally separated by the types of environmental management. That is in some ways obsolete and inefficient interpretation. This approach has been effective in law and in society, subordinated administrative-command economy, where management of all spheres of public and political life makes without democratic principles.

Nowadays, the main requirement of sustainable development defines in national law and national law doctrine close relationship of environmental governance and public environmental management, and exception departmental environmental management system that is outdated and inefficient way to control the management of natural resources, compliance with legislation on environmental protection and others. Departmental environmental management practice creates conflict moments of regulation and bureaucracy provides a significant interaction between the public and state environmental management environmental management.

\section{Discussion}

Thus, the public environmental management is the foundation for sustainable development in international environmental governance, and hence the institutional basis of public participation in the formation of a new legal understanding of the term. International environmental law doctrine proposes to determine the state of the driving force of international environmental governance and public participation will be a catalyst for development. We consider it appropriate to use this model for national environmental management as nominal and the real state of public environmental management is not the same, and therefore makes it impossible effectively exercise their rights. Recognition of the problem will enable more efficient ways to reform that have become effective on the international stage, so there is a significant possibility of their implementation in the national system. In the future, prospective studies seen the details of the public participation in international environmental governance, and the development of public environmental management as a separate element of environmental management that generates sustainable development. The public participants with the right of voice need to comply with such requirements: higher education, legal, environmental, natural, MBA of private sector, have experience / and / or take specialized courses or training and have a confirmation of a single international body, which defines conceptual directions of sustainable development.

\section{Reference}

1. Kennan, George F (1970)'To Prevent a World Wasteland: A Proposal'// F. George Kennan / Foreign Affairs 48, April, №3, 401-413.

2. Johnson, Brian. (1972) 'The United Nations Institutional Response to Stockholm: A Case Study in the International Politics of Institutional Change', International Organization 26, 2, 255-301.

3. Caldwell, Lynton Keith (1984) International Environmental Policy: Emergence and Dimensions, Durham NC: Duke University Press, 367. 
4. Krasner, Stephen D. (ed.) (1983) International Regimes, Ithaca: Cornell University Press, NBN International, 384.

5. Young, Oran R. (ed.) (1997), Global Governance. Drawing Insights from the Environmental Experience, Cambridge, Mass.: MIT Press, 348.

6. Bernauer, Thomas (1995) 'The Effect of International Environmental Institutions', International Organization 49, 2, 351-377.

7. Mitchell, Ronald B. and Thomas Bernauer (1998) 'Empirical Research on International Environmental Policy: Designing Qualitative Case Studies', Journal of Environment and Development № 7, 1, 4 31.

8. Zürn, Michael (1998) 'The Rise of International Environmental Politics', World Politics 50, 4, 617-649.

9. Barbara Gemmill and Abimbola Bamidele-Izu. The Role of NGOs and Civil Society in Global Environmental Governance. Yale School of Forestry \& Environmental Studies, 24. - Available from: http://environment.yale.edu/publication-series/documents/downloads/a-g/gemmill.pdf

10. UNEP, Guidelines for Participation of Major Groups and Stakeholders in Policy Design (Nairobi, 2010). Available from: http://www.pnuma.org/sociedad_civil/reunion2013/documentos/STAKEHOLD ER\%20PARTICIPATION/2009\%20UNEP\%20Guidelines-for-CSO-participation.pdf

11. Werksman, J.; Foti, J. UNEP Perspectives Issue No.1: Discussion Paper: Improving Public Participation in International Environmental Governance / Werksman, J.; Foti, J. / Nairobi, Kenya, UNEP, 2011, 16.

12. Meidinger, Errol (2001). "Law Making by Global Civil Society: The Forest Certification Prototype." Baldy Center for Law and Social Policy, State University of New York at Buffalo, Buffalo, NY. Available from: http://www.iue.it/LAW/joerges/transnationalism/documents/Meidinger.pdf

13. Reforming International Environmental Governance : From Institutional Limits to Innovative Reforms (2005) / ed. by W. Bradnee Chambers and Jessica F. Green / Reforming international environmental governance: From institutional limits to innovative reforms/ Publisher Tokyo [etc.] : United Nations University Press, 13-39. 